\title{
Extent of adoption of KAU practices on chilli cultivation in the homesteads of Kollam district
}

\author{
Vani Chandran* and Bindu Podikunju ${ }^{1}$ \\ Department of Agricultural Extension (K.A.U.), College of Agriculture, Vellayani, (Kerala) India \\ (Email: vaniagri93@gmail.com)
}

\begin{abstract}
Chilli is one of the important vegetable grown in homesteads of Kerala. In order to increase the production and income of chilli it is essential to improve the knowledge level and rate of adoption of scientific cultivation practices. Looking to the importance of chilli, it is essential that homestead growers of the state should be motivated for adopting various scientific cultivation practices.Hence, the present study was carried out with an objective, to know the extent of adoption of KAU practices on chilli cultivation by the homestead vegetable growers.From the study we can conclude that majority of the farmers adopted KAU varieties and they follow various cultural practices like seed treatments, seed rate, land preparation, weeding and application of manures as per the recommendations of package of practice and the least adopted practices were seasonality in cultivation and use of soil fumigants or plant protection measures.
\end{abstract}

Key Words : Extent of adoption, KAU recommended practices, Chilli cultivation, Homestead vegetable growers

View Point Article : Chandran, Vani and Podikunju, Bindu (2020). Extent of adoption of KAU practices on chilli cultivation in the homesteads of Kollam district. Internat. J. agric. Sci., 16 (1) : 45-47, DOI:10.15740/HAS/IJAS/16.1/45-47. Copyright@ 2020: Hind AgriHorticultural Society.

Article History : Received : 07.10.2019; Revised : 08.11.2019; Accepted : 11.12.2019

\footnotetext{
* Author for correspondence:

${ }^{1}$ Krishi Vigyan Kendra (K.A.U.) Sadanandapuram, Kollam (Kerala) India
} 